University of Nebraska - Lincoln

DigitalCommons@University of Nebraska - Lincoln

USDA National Wildlife Research Center - Staff Publications
U.S. Department of Agriculture: Animal and Plant Health Inspection Service

2013

\title{
Avian mortality at communication towers in the United States and Canada: which species, how many, and where?
}

Travis Longcore

The Urban Wildlands Group, longcore@urbanwildlands.org

Catherine Rich

The Urban Wildlands Group, crich@urbanwildlands.org

Pierre Mineau

National Wildlife Research Centre, Pierre.Mineau@ec.gc.ca

Beau MacDonald

The Urban Wildlands Group, beaumacdonald@sbcglobal.net

Daniel G. Bert

Carleton University, dan.bert@glel.carleton.ca

See next page for additional authors

Follow this and additional works at: https://digitalcommons.unl.edu/icwdm_usdanwrc

Part of the Life Sciences Commons

Longcore, Travis; Rich, Catherine; Mineau, Pierre; MacDonald, Beau; Bert, Daniel G.; Sullivan, Lauren M.; Mutrie, Erin; Gauthreaux, Sidney A. Jr.; Avery, Michael L.; Crawford, Robert L.; Manville, Albert M. II; Travis, Emilie R.; and Drake, David, "Avian mortality at communication towers in the United States and Canada: which species, how many, and where?" (2013). USDA National Wildlife Research Center - Staff Publications. 1162.

https://digitalcommons.unl.edu/icwdm_usdanwrc/1162

This Article is brought to you for free and open access by the U.S. Department of Agriculture: Animal and Plant Health Inspection Service at DigitalCommons@University of Nebraska - Lincoln. It has been accepted for inclusion in USDA National Wildlife Research Center - Staff Publications by an authorized administrator of DigitalCommons@University of Nebraska - Lincoln. 


\section{Authors}

Travis Longcore, Catherine Rich, Pierre Mineau, Beau MacDonald, Daniel G. Bert, Lauren M. Sullivan, Erin Mutrie, Sidney A. Gauthreaux Jr., Michael L. Avery, Robert L. Crawford, Albert M. Manville II, Emilie R.

Travis, and David Drake 


\title{
Avian mortality at communication towers in the United States and Canada: which species, how many, and where?
}

\author{
Travis Longcore ${ }^{\mathrm{a}, \mathrm{b}, *}$, Catherine Rich ${ }^{\mathrm{a}}$, Pierre Mineau ${ }^{\mathrm{c}}$, Beau MacDonald ${ }^{\mathrm{a}}$, Daniel G. Bert ${ }^{\mathrm{d}}$, \\ Lauren M. Sullivan $^{\text {e }}$, Erin Mutrie ${ }^{\mathrm{c}}$, Sidney A. Gauthreaux Jr. ${ }^{\mathrm{f}}$, Michael L. Avery ${ }^{\mathrm{g}}$, Robert L. Crawford ${ }^{\mathrm{h}}$, \\ Albert M. Manville II ${ }^{\mathrm{i}}$, Emilie R. Travis ${ }^{\mathrm{j}}$, David Drake ${ }^{\mathrm{j}}$ \\ ${ }^{a}$ The Urban Wildlands Group, P.O. Box 24020, Los Angeles, CA 90024, USA \\ ${ }^{\mathrm{b}}$ Spatial Sciences Institute, University of Southern California, Los Angeles, CA 90089, USA \\ ${ }^{\mathrm{c}}$ National Wildlife Research Centre, Science and Technology Branch, Environment Canada, Ottawa, Canada \\ ${ }^{\mathrm{d}}$ Geomatics and Landscape Ecology Research Laboratory, Carleton University, Ottawa, ON, Canada \\ e Department of Geography, University of California, Los Angeles, CA 90024, USA \\ ${ }^{\mathrm{f}}$ Department of Biological Sciences, Clemson University, Clemson, SC 29634, USA \\ ${ }^{\mathrm{g}}$ United States Department of Agriculture/Wildlife Services, National Wildlife Research Center, Florida Field Station, 2820 East University Avenue, Gainesville, FL 32641, USA \\ h 208 Junius Street, Thomasville, GA 31792, USA \\ ${ }^{\mathrm{i}}$ U.S. Fish and Wildlife Service, Division of Migratory Bird Management, 4401 N. Fairfax Dr. - MBSP-4107, Arlington, VA 22203, USA \\ j University of Wisconsin, Department of Forest \& Wildlife Ecology, Madison, WI 53706, USA
}

\section{A R T I C L E I N F O}

\section{Article history:}

Received 30 June 2012

Received in revised form 20 September 2012

Accepted 24 September 2012

\section{Keywords:}

Communication towers

Mortality

Night lighting

Neotropical migrants

Collisions

Impact assessment

\begin{abstract}
A B S T R A C T
Birds migrating to and from breeding grounds in the United States and Canada are killed by the millions in collisions with lighted towers and their guy wires. Avian mortality at towers is highly variable across species, and the importance to each population depends on its size and trajectory. Building on our previous estimate of avian mortality at communication towers, we calculated mortality by species and by regions. To do this, we constructed a database of mortality by species at towers from available records and calculated the mean proportion of each species killed at towers within aggregated Bird Conservation Regions. These proportions were combined with mortality estimates that we previously calculated for those regions. We then compared our estimated bird mortality rates to the estimated populations of these species in the United States and Canada. Neotropical migrants suffer the greatest mortality; 97.4\% of birds killed are passerines, mostly warblers (Parulidae, 58.4\%), vireos (Vireonidae, 13.4\%), thrushes (Turdidae, 7.7\%), and sparrows (Emberizidae, 5.8\%). Thirteen birds of conservation concern in the United States or Canada suffer annual mortality of 1-9\% of their estimated total population. Of these, estimated annual mortality is $>2 \%$ for Yellow Rail (Coturnicops noveboracensis), Swainson's Warbler (Limnothlypis swainsonii), Pied-billed Grebe (Podilymbus podiceps), Bay-breasted Warbler (Setophaga castanea), Golden-winged Warbler (Vermivora chrysoptera), Worm-eating Warbler (Helmitheros vermivorum), Prairie Warbler (Setophaga discolor), and Ovenbird (Seiurus aurocapilla). Avian mortality from anthropogenic sources is almost always reported in the aggregate ("number of birds killed"), which cannot detect the species-level effects necessary to make conservation assessments. Our approach to per species estimates could be undertaken for other sources of chronic anthropogenic mortality.
\end{abstract}

(c) 2012 Elsevier Ltd. All rights reserved.
* Corresponding author. Address: The Urban Wildlands Group, P.O. Box 24020, Los Angeles, CA 90024, USA. Tel.: +1 3102479719.

E-mail addresses: longcore@urbanwildlands.org (T. Longcore), crich@ urbanwildlands.org (C. Rich), Pierre.Mineau@ec.gc.ca (P. Mineau), beaumacdonald@ sbcglobal.net (B. MacDonald), dan.bert@glel.carleton.ca (D.G. Bert), laurenmsullivan@ gmail.com (L.M. Sullivan), er339081@dal.ca (E. Mutrie), gocajuns@bellsouth.net (S.A. Gauthreaux Jr.), Michael.L.Avery@aphis.usda.gov (M.L. Avery), rlcrawfd@rose.net (R.L. Crawford), Albert_Manville@fws.gov (A.M. Manville II), uvem05@gmail.com (E.R. Travis), ddrake2@wisc.edu (D. Drake).

\section{Introduction}

Avian mortality from collisions with human-made structures is an issue of ongoing conservation concern (Drewitt and Langston, 2008; Longcore et al., 2008, 2012; Manville, 2005, 2009). Mortality at communication towers has generated long-term studies at single sites (e.g., Crawford and Engstrom, 2001; Kemper, 1996), many incidental observations (Avery et al., 1980; Kerlinger, 2000; Trapp, 1998; Weir, 1976), and comparative studies across towers in several regions (Gehring et al., 2009; Johnston and Haines, 1957; Morris et al., 2003; Seets and Bohlen, 1977). The U.S. Fish and 
Wildlife Service (USFWS) has estimated avian mortality from communication towers at 4-5 million birds per year and released guidelines designed to minimize such mortality (U.S. Fish and Wildlife Service, 2000). We derived an updated estimate of 6.8 million birds per year with a tower height-mortality regression and the characteristics of $>70,000$ towers demonstrating that mortality increases predictably with tower height (Longcore et al., 2012). The USFWS has made recommendations to the Federal Communications Commission (FCC) on how to further reduce incidental take (Manville, 2007) and Environment Canada is currently assessing incidental mortality of migratory bird species at towers as part of a comprehensive effort to address all sources of incidental mortality.

Avian mortality at communication towers occurs most frequently when nocturnal migrants are attracted to tower lights. Birds that enter the zone of influence of lights then circle the towers and are at risk of death from exhaustion, collision with the tower and its guy wires, and collisions with each other (Gauthreaux and Belser, 2006). This usually occurs in inclement weather when other navigational cues are obscured and around the time of passage of cold fronts that drive birds down to altitudes where they are more likely to encounter towers and their lights (Avery et al., 1976).

Estimates of mortality for individual species are needed to assess biological significance of avian mortality at communication towers (Longcore et al., 2005, 2012). The term biological significance is not formally defined in the context of environmental impact assessment, but a logical definition might be that a biologically significant impact would adversely affect a species or its habitat and could be expected to affect the population growth or stability of the species and influence the population's long-term viability. Others have concluded that what constitutes a biologically significant population change is not easy to define (Reed and Blaustein, 1997). It may be important to understand the degree to which population growth is suppressed by a mortality source (Loss et al., 2012). Any change in a population has some biological consequence to other species, and therefore any population decline could be important and determining whether it is "significant" may be arbitrary. Biological significance in this context should not be confused with a statistically significant trend in a biological variable. Although statistical significance may influence the judgment about whether an impact is biologically significant, it is not a prerequisite.

To evaluate the biological significance of mortality, species or populations should be the unit of analysis in most instances. For example, barbed wire fences kill a relatively small proportion of birds compared with such hazards as windows and free-roaming cats, but barbed wire fences are a biologically significant source of mortality for Whooping Cranes (Grus americana), an endangered species (Allen and Ramirez, 1990). Higher taxonomic groups, such as families or even guilds that cut across taxonomic groups, may be the appropriate unit of analysis if something is known about the conservation status of the units as a whole. For example, oil pits (pits where oil producers dispose of waste fluids) kill an estimated $500,000-1,000,000$ birds per year (Trail, 2006). This raw number can be interpreted with the knowledge that 162 species have been killed in oil pits, of which $63 \%$ were ground-feeding birds, including several species of conservation concern (Trail, 2006). Mortality at communication towers, up to this point, has been a conservation issue because the species predominantly killed at towers are Neotropical migratory songbirds, which are of conservation concern as a group. Beyond this general observation, however, only crude estimates have been made of the species composition of the millions of birds killed annually at communication towers (Arnold and Zink, 2011; Shire et al., 2000).

Arnold and Zink (2011) performed an analysis of the proportion of birds killed at towers and regressed the relative risk of collision against 30-year population trends calculated from Breeding Bird Survey data. They concluded from this regression that tower mortality had no discernible effect on population trajectories and claimed that their methods had statistical power to detect as little as a $4.1 \%$ contribution to the observed trends. Arnold and Zink (2011) have been criticized for their methods (Schaub et al., 2011) and for the scope of their inferences (Klem et al., 2012), and we have several additional concerns about their analysis. First, they used a flawed secondary data source (Shire et al., 2000) as their raw data for tower mortality. Shire et al. (2000) included a single list of the number of each species killed at towers, which they obtained by summing the results from 47 towers for which they found data. This unpublished report, however, did not exhaustively cover the literature available at the time, contained tabulation errors, and is now dated. It also presents raw sums, which are heavily influenced by the length of the various studies and do not account for regional variation in mortality. Arnold and Zink (2011) identified species that were killed more or less frequently than expected based on population sizes, but because they failed to obtain the primary sources, their mortality proportions contain the errors inherent in the Shire et al. (2000) report and do not account for regional variation or provide a mechanism to combine studies of different lengths in a way that keeps large datasets from overwhelming smaller ones. Failing to account for geographic variability leads to the unrealistic assumption that each tower in North America kills exactly the same proportion of each species of bird. Furthermore, we are unconvinced that impacts of collision mortality would be seen across hundreds of species in the manner assumed by Arnold and Zink (2011). Rather, it is much more likely that tower mortality represents one of an array of stressors affecting the population trajectories of a more limited number of species. In short, we doubt the ability of their method to definitively identify the cumulative impacts of avian mortality at towers and buildings, and make no such sweeping claim for the approach we develop here.

To better understand the effects of avian mortality at communication towers, we combine our previous geographically stratified estimate of total avian mortality at communication towers (Longcore et al., 2012) with estimates of the proportion of each bird species killed within different regions to develop geographically explicit tallies of avian mortality at communication towers by species. We chose geographically specific estimates because avian mortality and tower height vary regionally, and this additional information should be incorporated into any estimates. We then compare these per species mortality estimates with population estimates for these species to gauge the magnitude of this mortality source on a species-by-species basis.

\section{Methods}

An estimate of the number of each avian species killed at towers annually can be obtained by multiplying an estimate of total avian mortality for a region by the average proportion of each species found in kills at towers in that region. We previously developed an estimate of avian mortality at communication towers in the United States and Canada by Bird Conservation Region (BCR) (Longcore et al., 2012). This estimate was built from a regression relating tower height to annual mortality first developed by Longcore et al. (2005, 2008). The more recent estimate adjusted the raw annual mortality data obtained from existing studies for search efficiency, scavenging, and the sampling scheme (Longcore et al., 2012). The finding of lower avian mortality rates at towers without guy wires and without steady-burning lights (Gehring et al., 2009) was incorporated in these estimates. The corrected relationship between tower height and mortality was then applied to the towers 


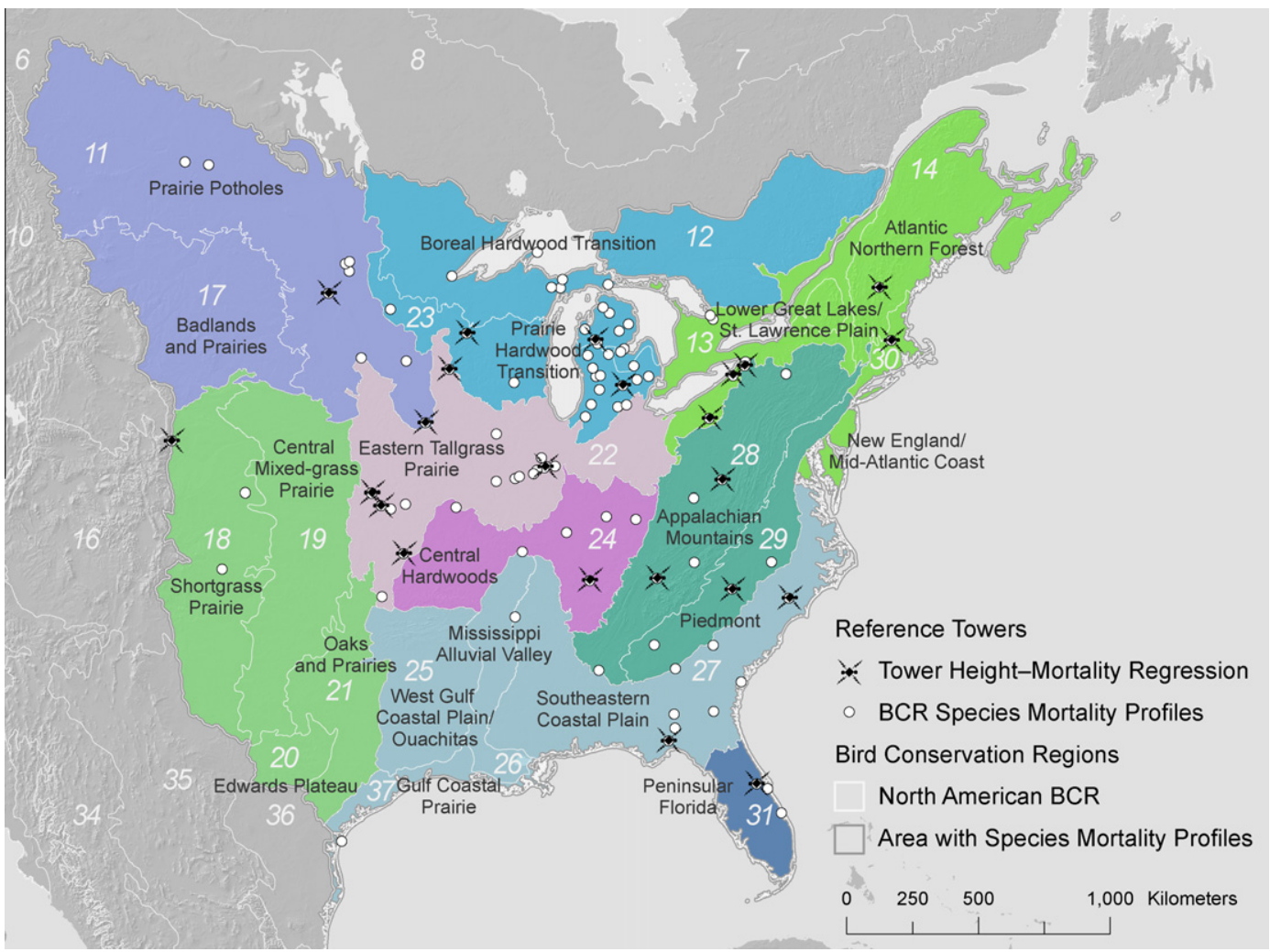

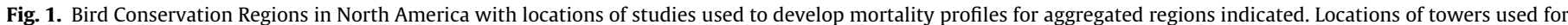
height-mortality regression are also shown (see Longcore et al., 2012).

Table 1

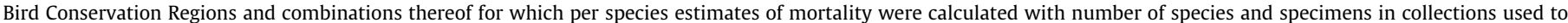
describe the regional mortality profile.

\begin{tabular}{|c|c|c|c|c|}
\hline Bird Conservation Regions (References) & \# Species & \# Specimens & \# Locations & Estimated Mortality ${ }^{\mathrm{a}}$ \\
\hline $\begin{array}{l}\text { Southeastern Coastal Plain, Mississippi Alluvial Valley, West Gulf Coastal Plain/Ouachitas, } \\
\text { Gulf Coastal Prairie }\end{array}$ & 192 & 64 & 5 & 56 \\
\hline \multicolumn{5}{|c|}{ Carter and Parnell (1976, 1978), Crawford (1976), Crawford and Engstrom (2001), James (1956), Johnston (1955, 1957), Johnston and Haines (1957), and Teulings (1972) } \\
\hline \multicolumn{5}{|c|}{$\begin{array}{l}\text { Boso (1965), Brewer and Ellis (1958), Cochran and Graber (1958), Gregory (1975), Kleen and Bush (1973), Mosman (1975), Norman (1987), Parmalee and Parmalee } \\
\text { (1959), Parmalee and Thompson (1963), Petersen (1959), Robbins et al. (2000), Seets and Bohlen (1977), and Young and Robbins (2001) }\end{array}$} \\
\hline \multicolumn{5}{|c|}{$\begin{array}{l}\text { Alsop and Wallace (1969), Bierly (1968, 1969), Ellis (1997), Herndon (1973), Herron (1997) Nicholson (1984), Norwood (1960), Remy (1974, 1975), Rosche (1971), } \\
\text { Trott (1957), Turner and Davis (1980), and Welles (1978) }\end{array}$} \\
\hline $\begin{array}{l}\text { Shortgrass Prairie, Central Mixed-grass Prairie, Edwards Plateau, Oaks and Prairies } \\
\text { Barkley et al. (1977), Nielsen and Wilson (2006), and Young (1993) }\end{array}$ & 65 & 611 & 3 & $1,128,718$ \\
\hline \multicolumn{5}{|c|}{$\begin{array}{l}\text { Caldwell and Cuthbert (1963), Caldwell and Wallace (1966), Feehan (1963), Gehring et al. (2009), Green (1963), Kemper (1996), Kemper et al. (1966), Manuwal } \\
\text { (1963), Sharp (1971), Strnad (1962, 1975), and Travis (2009) }\end{array}$} \\
\hline \multicolumn{5}{|c|}{$\begin{array}{l}\text { Able (1966), Anonymous (1961), Barbour (1961), Bierly (1973), Elder and Hansen (1967), Ganier (1962), George (1963), Goodpasture (1974a,b, 1975, 1976, 1984, } \\
\text { 1986, 1987), Laskey (1962, 1963, 1964, 1967, 1968, 1969a,b, 1971), Nehring and Bivens (1999), and Palmer-Ball and Rauth (1990) }\end{array}$} \\
\hline $\begin{array}{l}\text { Peninsular Florida } \\
\qquad \text { Case et al. (1965), Kale (1971), and Taylor and Anderson }(1973,1974)\end{array}$ & 98 & 15,261 & 4 & 341,774 \\
\hline $\begin{array}{l}\text { Prairie Potholes, Badlands and Prairies } \\
\text { Avery and Clement (1972), Avery et al. (1978), Ball et al. (1995), Houston and Houston (19) } \\
\text { (1961, 1962), Pierce (1969), and Young and Robbins (2001) }\end{array}$ & $\begin{array}{l}125 \\
\text { Janssen }(\end{array}$ & $\begin{array}{l}2520 \\
3), \text { Kemper }\end{array}$ & 8 & $\begin{array}{l}382,315 \\
959,1962,1965), \text { Nero }\end{array}$ \\
\hline $\begin{array}{l}\text { New England/Mid-Atlantic Coast, Atlantic Northern Forest, Lower Great Lakes/St. Lawrence Plain } \\
\text { Baird (1970, 1971), Sawyer (1961), and Westman (1967) }\end{array}$ & 71 & 3375 & 3 & 285,405 \\
\hline
\end{tabular}

\footnotetext{
a From Longcore et al. (2012).
} 
in each BCR, extracted from digital geographic records for the United States and Canada. The resulting estimate, calculated by BCR, totaled 6.8 million birds per year (Longcore et al., 2012).

\subsection{Development of per species mortality estimates}

We used the approach described by Longcore et al. (2005) to assign the estimated total mortality to individual species. We conducted an extensive literature search to identify published reports of avian mortality at towers that included complete lists of birds killed. We located these studies from previous reviews (Avery et al., 1980; Kerlinger, 2000; Shire et al., 2000; Trapp, 1998; Weir, 1976) and directly from other researchers. We obtained copies of each report and transferred the number of each species recorded dead at each tower to a spreadsheet. For multiple studies of the same or adjacent towers we summed all observations of each species. We used raw numbers to develop the mortality proportions at each location and did not adjust for scavenging or search efficiency because $>97 \%$ of the birds were passerines and such differences in detectability and scavenging would be unlikely to have a substantial effect. We also included all species lists without consideration of date of study to avail ourselves of the maximum number of specimens to develop regional profiles.

To develop profiles of birds killed within each BCR we calculated the proportion $(P)$ of each bird species killed at each tower site within the region and took the mean of these proportions weighted by the number of species $(S)$ documented at that location as follows

$P_{\mathrm{BCR}}=\frac{\sum_{1}^{n} P_{i} \times S_{i}}{\sum_{1}^{n} S_{i}}$

where $n$ is the number of studies in the BCR. We weighted by species number because species number increases rapidly with study length (measured in number of nights sampled) but quickly reaches an asymptote (unpublished results). By using species number as a weight, we emphasize those studies with greater sampling but do not overemphasize the exceptionally long studies or completely discard short studies that may have recorded a small but diverse sample of birds. Because we only use this weighting within geographic regions, it is not prone to the bias of geographic variations in species richness suggested by Loss et al. (2012).

We multiplied the proportion of each species killed within each BCR for which there were records by the estimated annual mortality derived from the tower data and associated regressions (Longcore et al., 2012) to produce estimates of the numbers of birds killed of each species within those BCRs.

When avian mortality had been recorded at towers in a BCR, but fewer than 3 studies were available to produce a species profile, we combined BCRs for analysis. We also included BCRs where avian mortality at towers had not been recorded but would be expected based on geography (e.g., mortality recorded in adjacent BCRs). Specifically, we combined Prairie Potholes $(n=8)$ and Badlands and Prairies $(n=0)$; Lower Great Lakes/St. Lawrence Plain $(n=2)$, New England/Mid-Atlantic Coast $(n=2)$, and Atlantic Northern Forest $(n=0)$; Southeastern Coastal Plain $(n=4)$, Mississippi Alluvial Valley $(n=0)$, West Gulf Coastal Plain/Ouachitas $(n=0)$, and Gulf Coastal Prairie $(n=1)$; Prairie Hardwood Transition $(n=12)$ and Boreal Hardwood Transition ( $n=1)$; Appalachian Mountains $(n=6)$ and Piedmont $(n=2)$; and Shortgrass Prairie $(n=3)$, Central Mixed-grass Prairie $(n=0)$, Edwards Plateau $(n=0)$, and Oaks and Prairies $(n=0)$ (Fig. 1). For Gulf Coastal Prairie we included a record of mortality at streetlights (James, 1956) to develop the species profile because no searches of towers had been reported in the literature from this region. The streetlight kill illustrated the ability of lighted structures to kill migratory birds in this region by attracting and drawing birds down to near ground level. We did not assign the bird mortality to species in BCRs in the western United States and Canada where no studies or only single very short studies were found (Dickerman et al., 1998; Ginter and Desmond, 2004).

Ideally, we would have compared mortality to individual populations of species within BCRs. This is not possible because tower mortality occurs mostly during migration and mortality cannot be connected to local populations. We instead compared per species mortality estimates with estimates of total United States and Canada populations that are available for conservation planning purposes (Brown et al., 2001; Kushlan et al., 2002; North American Waterfowl Management Plan Committee, 2004; Rich et al., 2004). To assess the status of species killed at towers, we cross-referenced them with the most recent list of Birds of Conservation Concern issued by the U.S. Fish and Wildlife Service (2008), the United States and International Union for Conservation of Nature (IUCN) endangered species lists, and the Canadian Species at Risk schedules (http://www.sararegistry.gc.ca/). We regressed $\log _{10}$-transformed total estimated mortality for each species by $\log _{10}$-transformed population size to evaluate whether species are killed in proportion to their population size.

\section{Table 2}

Annual avian mortality at communication towers in central and eastern North America by Order, with subtotals by Family in Passeriformes. Only includes BCRs or merged BCRs for which mortality profiles could be developed from more than 1000 specimens.

\begin{tabular}{|c|c|c|c|}
\hline Order & $\begin{array}{l}\text { Number of } \\
\text { species }\end{array}$ & $\begin{array}{l}\text { Percent of total } \\
\text { mortality (\%) }\end{array}$ & $\begin{array}{l}\text { Total mortality } \\
\text { estimate }\end{array}$ \\
\hline Passeriformes & 146 & 97.35 & $5,125,205$ \\
\hline Parulidae & 39 & 58.42 & $3,075,659$ \\
\hline Vireonidae & 8 & 13.38 & 704,486 \\
\hline Turdidae & 7 & 7.68 & 404,203 \\
\hline Emberizidae & 24 & 5.78 & 304,343 \\
\hline Cardinalidae & 9 & 3.19 & 167,942 \\
\hline Mimidae & 4 & 2.89 & 151,898 \\
\hline Regulidae & 2 & 2.03 & 105,847 \\
\hline Icteridae & 10 & 1.64 & 86,301 \\
\hline Troglodytidae & 6 & 1.30 & 68,635 \\
\hline Tyrannidae & 9 & 0.55 & 29,040 \\
\hline Certhiidae & 1 & 0.13 & 6586 \\
\hline Calcariidae & 5 & 0.11 & 5939 \\
\hline Fringillidae & 6 & 0.08 & 4184 \\
\hline Bombycillidae & 1 & 0.05 & 2841 \\
\hline Sittidae & 2 & 0.03 & 1583 \\
\hline Sturnidae & 1 & 0.03 & 1559 \\
\hline Hirundinidae & 6 & 0.02 & 1201 \\
\hline Passeridae & 1 & 0.02 & 958 \\
\hline Corvidae & 2 & 0.01 & 668 \\
\hline Laniidae & 1 & 0.00 & 246 \\
\hline Motacillidae & 1 & 0.00 & 65 \\
\hline Polioptilidae & 1 & 0.00 & 22 \\
\hline Gruiformes & 9 & 0.97 & 51,102 \\
\hline Cuculiformes & 2 & 0.49 & 25,835 \\
\hline Piciformes & 7 & 0.35 & 18,358 \\
\hline Columbiformes & 3 & 0.32 & 16,685 \\
\hline Anseriformes & 15 & 0.14 & 7369 \\
\hline Podicipediformes & 4 & 0.11 & 6005 \\
\hline Ciconiiformes & 14 & 0.10 & 5200 \\
\hline Charadriiformes & 17 & 0.07 & 3623 \\
\hline Apodiformes & 1 & 0.04 & 2027 \\
\hline Galliformes & 5 & 0.03 & 1498 \\
\hline Caprimulgiformes & 3 & 0.02 & 1015 \\
\hline Coraciiformes & 1 & 0.00 & 226 \\
\hline Falconiformes & 2 & 0.00 & 146 \\
\hline Strigiformes & 2 & 0.00 & 65 \\
\hline Pelecaniformes & 1 & 0.00 & 58 \\
\hline Gaviiformes & 1 & 0.00 & 22 \\
\hline Procellariiformes & 1 & 0.00 & 22 \\
\hline
\end{tabular}




\section{Results}

\subsection{Estimates of birds killed by species}

We assigned mortality to species for the regions east of the Rocky Mountains with sufficient records to describe mortality profiles (Fig. 1). The studies contributing to these regional profiles documented 259,393 deaths of 239 species at 107 locations. After calculating per species estimates for a combined region of shortgrass prairie BCRs (Shortgrass Prairie, Central Mixed-grass Prairie, Edwards Plateau, Oaks and Prairies), we omitted these results from further reports because of the low number of specimens (611). In our previous analysis (Longcore et al., 2012), the remaining BCRs accounted for 5.26 million annual fatalities, or $77 \%$ of all mortality at towers in the United States and Canada. Our regional proportions allowed us to allocate these deaths to species, with $97.4 \%$ of estimated mortality consisting of passerines, with the greatest proportion being warblers (Parulidae, $58.4 \%$ of all mortality), vireos (Vireonidae, 13.4\%), thrushes (Turdidae, 7.7\%), and sparrows (Emberizidae, 5.8\%) (Table 2). For the regions where we report mortality by species, 234 species were recorded from tower sites. Our database of studies included additional species killed at towers in the shortgrass prairie regions and elsewhere, including Swainson's Hawk (Buteo swainsoni) and Hammond's Flycatcher (Empidonax hammondii) in New Mexico (Ginter and Desmond, 2004), and Short-tailed Shearwater (Puffinus tenuirostris), Fork-tailed StormPetrel (Oceanodroma furcata), Black-legged Kittiwake (Rissa tridactyla), Short-eared Owl (Asio flammeus) (Dickerman et al., 1998), Spectacled Eider (Somateria fischeri), and Steller's Eider (Polysticta stelleri) (E. Lance, U.S. Fish and Wildlife Service, pers. comm.) in Alaska.

\subsection{Comparison of per species tower mortality to population size}

Avian mortality at towers was estimated to be $\geqslant 1 \%$ of total population per year for 29 species (Table 3). Annual mortality was estimated to exceed $0.5 \%$ of population size for an additional 15 species. Fifty-four species identified as Birds of Conservation Concern (U.S. Fish and Wildlife Service, 2008), 1 federally endangered species, and $1 \mathrm{IUCN}$ endangered species have been killed at towers (Tables 3 and 4). Thirteen of the 20 bird species killed most frequently by percentage of population are identified as either Birds of Conservation Concern or endangered.

Warblers (Parulidae) are 15 of the 20 species most frequently killed and 12 of the 20 species with highest proportions killed. Some species from other groups show high mortality as a proportion of population size. For example, $9.0 \%$ of the population of Yellow Rails and $5.6 \%$ of Pied-billed Grebes are estimated to be killed at towers each year.

Regional mortality profiles do show marked differences, which are evident in the ranking of species killed in each region (Table 5). This provides evidence in support of a regional approach to estimate mortality. The correlation between population size and tower mortality is significant but has low explanatory value (regression of $\log _{10}$ transformed variables; coefficient $=0.56,95 \% \mathrm{CI}=0.40$ $\left.0.72 ; r^{2}=0.17 ; F_{1,224}=44.37, p<0.001\right)$.

\section{Discussion}

Many bird species are killed at towers disproportionate to their abundance. Tower mortality is, therefore, not a random factor affecting all migrating birds. Mayfield (1967) argued that mortality at towers did not affect bird populations in part because birds are

Table 3

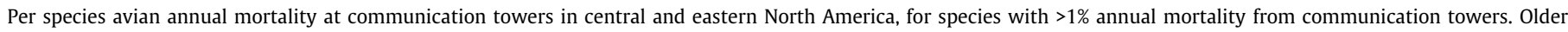

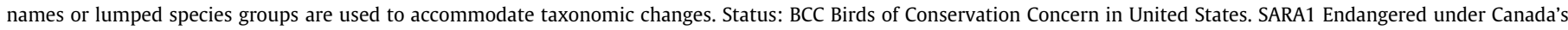
Species at Risk Act, SARA2 Threatened, and SARA3 Special Concern.

\begin{tabular}{|c|c|c|c|c|c|}
\hline Species & Family & $\begin{array}{l}\text { North Am. population } \\
\text { estimate }\end{array}$ & $\begin{array}{l}\text { Est. annual } \\
\text { mortality }\end{array}$ & $\begin{array}{l}\text { Percent of } \\
\text { population (\%) }\end{array}$ & Status \\
\hline Yellow Rail Coturnicops noveboracensis & Rallidae & $25,000^{\mathrm{b}}$ & 2245 & 9.0 & BCC/SARA3 \\
\hline Swainson's Warbler Limnothlypis swainsonii & Parulidae & $84,000^{\mathrm{a}}$ & 7473 & 8.9 & $\mathrm{BCC}$ \\
\hline Pied-billed Grebe Podilymbus podiceps & Podicipedidae & $100,000^{\mathrm{b}}$ & 5589 & 5.6 & BCC \\
\hline Bay-breasted Warbler Setophaga castanea & Parulidae & $3,000,000^{\mathrm{a}}$ & 165,257 & 5.5 & $\mathrm{BCC}$ \\
\hline Black-throated Blue Warbler Setophaga caerulescens & Parulidae & $2,000,000^{\mathrm{a}}$ & 98,578 & 4.9 & \\
\hline Golden-winged Warbler Vermivora chrysoptera & Parulidae & $210,000^{\mathrm{a}}$ & 5276 & 2.5 & BCC/SARA2 \\
\hline Kentucky Warbler Geothlypis formosa & Parulidae & $1,100,000^{\mathrm{a}}$ & 27,441 & 2.5 & \\
\hline Worm-eating Warbler Helmitheros vermivorum & Parulidae & $700,000^{a}$ & 16,153 & 2.3 & $\mathrm{BCC}$ \\
\hline Prairie Warbler Setophaga discolor & Parulidae & $1,400,000^{\mathrm{a}}$ & 30,401 & 2.2 & BCC \\
\hline Ovenbird Seiurus aurocapilla & Parulidae & $24,000,000^{\mathrm{a}}$ & 498,714 & 2.1 & \\
\hline Scarlet Tanager Piranga olivacea & Cardinalidae & $2,200,000^{\mathrm{a}}$ & 35,270 & 1.6 & \\
\hline Henslow's Sparrow Ammodramus henslowii & Emberizidae & $80,000^{\mathrm{a}}$ & 1261 & 1.6 & BCC/SARA1 \\
\hline Canada Warbler Cardellina canadensis & Parulidae & $1,400,000^{\mathrm{a}}$ & 20,622 & 1.5 & BCC/SARA2 \\
\hline Gray Catbird Dumetella carolinensis & Mimidae & $10,000,000^{\mathrm{a}}$ & 139,050 & 1.4 & \\
\hline Seaside Sparrow Ammodramus maritimus & Emberizidae & $110,000^{\mathrm{a}}$ & 1513 & 1.4 & $\mathrm{BCC}$ \\
\hline Louisiana Waterthrush Parkesia motacilla & Parulidae & $260,000^{\mathrm{a}}$ & 3572 & 1.4 & BCC/SARA3 \\
\hline Yellow-throated Vireo Vireo flavifrons & Vireonidae & $1,400,000^{\mathrm{a}}$ & 17,402 & 1.2 & \\
\hline Common Yellowthroat Geothlypis trichas & Parulidae & $32,000,000^{\mathrm{a}}$ & 386,484 & 1.2 & \\
\hline Connecticut Warbler Oporornis agilis & Parulidae & $1,200,000^{\mathrm{a}}$ & 14,324 & 1.2 & \\
\hline Trumpeter Swan Cygnus buccinator & Anatidae & $23,647^{\mathrm{c}}$ & 280 & 1.2 & \\
\hline Chestnut-sided Warbler Setophaga pensylvanica & Parulidae & $9,400,000^{\mathrm{a}}$ & 108,634 & 1.2 & \\
\hline Black-and-white Warbler Mniotilta varia & Parulidae & $14,000,000^{\mathrm{a}}$ & 149,485 & 1.1 & \\
\hline Hooded Warbler Setophaga citrina & Parulidae & $4,000,000^{\mathrm{a}}$ & 41,551 & 1.0 & \\
\hline Blackburnian Warbler Setophaga fusca & Parulidae & $5,900,000^{\mathrm{a}}$ & 60,487 & 1.0 & \\
\hline Blue-winged Warbler Vermivora cyanoptera & Parulidae & $390,000^{\mathrm{a}}$ & 3852 & 1.0 & BCC \\
\hline Prothonotary Warbler Protonotaria citrea & Parulidae & $1,800,000^{\mathrm{a}}$ & 17,645 & 1.0 & BCC/SARA1 \\
\hline Philadelphia Vireo Vireo philadelphicus & Vireonidae & $4,000,000^{\mathrm{a}}$ & 38,431 & 1.0 & \\
\hline Cape May Warbler Setophaga tigrina & Parulidae & $3,000,000^{\mathrm{a}}$ & 28,731 & 1.0 & \\
\hline
\end{tabular}

\footnotetext{
a Rich et al. (2004).

b Kushlan et al. (2002).

c North American Waterfowl Management Plan Committee (2004).
} 
Table 4

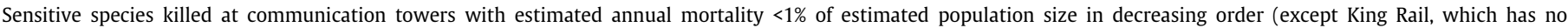

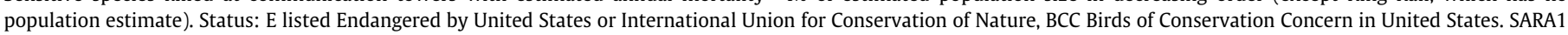
Endangered under Canada's Species at Risk Act, SARA2 Threatened, and SARA3 Special Concern.

\begin{tabular}{|c|c|c|c|}
\hline Blue-winged Warbler Vermivora cyanoptera & BCC & Field Sparrow Spizella pusilla & $\mathrm{BCC}$ \\
\hline Prothonotary Warbler Protonotaria citrea & BCC/SARA1 & American Bittern Botaurus lentiginosus & $\mathrm{BCC}$ \\
\hline Northern Parula Setophaga americana & $\mathrm{BCC}$ & Rusty Blackbird Euphagus carolinus & $\mathrm{BCC}$ \\
\hline Black-capped Petrel Pterodroma hasitata & $\mathrm{E}$ & Song Sparrow Melospiza melodia & $\mathrm{BCC}$ \\
\hline Cerulean Warbler Setophaga cerulea & BCC/SARA3 & Marsh Hawk (Northern Harrier) Circus cyaneus & $\mathrm{BCC}$ \\
\hline Least Bittern Ixobrychus exilis & SARA2 & Painted Bunting Passerina ciris & $\mathrm{BCC}$ \\
\hline Blackpoll Warbler Setophaga striata & $\mathrm{BCC}$ & Red-headed Woodpecker Melanerpes erythrocephalus & SARA2 \\
\hline Bachman's Sparrow Peucaea aestivalis & BCC & Solitary Sandpiper Tringa solitaria & $\mathrm{BCC}$ \\
\hline Black-throated Green Warbler Setophaga virens & BCC & Little Blue Heron Egretta caerulea & $\mathrm{BCC}$ \\
\hline Bobolink Dolichonyx oryzivorus & $\mathrm{BCC}$ & McCown's Longspur Rhynchophanes mccownii & BCC/SARA3 \\
\hline Black Rail Laterallus jamaicensis & BCC & Chimney Swift Chaetura pelagica & SARA2 \\
\hline $\begin{array}{l}\text { Sharp-tailed Sparrow (Nelson's \& Saltmarsh) } \\
\text { Ammodramus nelsoni, Ammodramus caudacutus }\end{array}$ & $\mathrm{BCC}$ & White Ibis Eudocimus albus & BCC \\
\hline Yellow-billed Cuckoo Coccyzus americanus & BCC & Upland Sandpiper Bartramia longicauda & $\mathrm{BCC}$ \\
\hline Marsh Wren Cistothorus palustris & $\mathrm{BCC}$ & Horned Grebe Podiceps auritus & $\mathrm{BCC}$ \\
\hline Yellow-breasted Chat Icteria virens & SARA3 & Common Tern Sterna hirundo & BCC \\
\hline Le Conte's Sparrow Ammodramus leconteii & $\mathrm{BCC}$ & Loggerhead Shrike Lanius ludovicianus & BCC/SARA1 \\
\hline Sedge Wren Cistothorus platensis & $\mathrm{BCC}$ & Common Nighthawk Chordeiles minor & SARA2 \\
\hline Red-cockaded Woodpecker Picoides borealis & $\mathrm{E}$ & Chestnut-collared Longspur Calcarius ornatus & $\mathrm{BCC}$ \\
\hline Black-whiskered Vireo Vireo altiloquus & BCC & Eared Grebe Podiceps nigricollis & $\mathrm{BCC}$ \\
\hline Grasshopper Sparrow Ammodramus savannarum & $\mathrm{BCC}$ & Sage Thrasher Oreoscoptes montanus & $\mathrm{BCC}$ \\
\hline Western Grebe Aechmophorus occidentalis & BCC & Black-throated Gray Warbler Setophaga nigrescens & BCC \\
\hline Yellow Warbler Setophaga petechia & $\mathrm{BCC}$ & Lark Bunting Calamospiza melanocorys & $\mathrm{BCC}$ \\
\hline Acadian Flycatcher Empidonax virescens & BCC/SARA1 & Northern Bobwhite Colinus virginianus & SARA1 \\
\hline Harris's Sparrow Zonotrichia querula & $\mathrm{BCC}$ & Semipalmated Sandpiper Calidris pusilla & $\mathrm{BCC}$ \\
\hline Bell's Vireo Vireo bellii & BCC & American Pipit Anthus rubescens & SARA2 \\
\hline Savannah Sparrow Passerculus sandwichensis & SARA3 & Olive-sided Flycatcher Contopus cooperi & SARA2 \\
\hline Dickcissel Spiza americana & $\mathrm{BCC}$ & King Rail Rallus elegans & SARA1 \\
\hline
\end{tabular}

killed at towers in proportion to their abundance. More recently Arnold and Zink (2011) claimed that population size explained almost $43 \%$ of variation in tower collision mortality. Our results show that some species experience mortality far out of proportion with their population size (Fig. 2), as was also shown by Graber (1968), and that population size only explains $18 \%$ of variation in tower mortality. Our divergence from Arnold and Zink's (2011) results is most likely attributable to methodological differences in developing species proportions. They did not account for regional variation in mortality or differentially weight the contribution of different tower studies, but rather simply pooled all mortalities at all towers at all locations to develop the proportions of birds killed.

Our estimates indicate that some species of birds experience mortality from towers up to several percent of their total population each year. Neotropical migrants are most affected by collisions with communication towers. For these species, the migratory period has been suspected to be "the critical period contributing to long-term declines in some species" (Hutto, 2000). Sillett and Holmes (2002) presented a long-term study of Black-throated Blue Warbler, one of many species killed at communications towers (our estimate is $\sim 55,000$ per year). They found that survival of individuals was high during the summer $(0.99 \pm 0.01)$ and winter $(0.93 \pm 0.05)$, while survival during both spring and fall migration was only $0.67-0.73$. Their study was the first quantification of migration mortality for a Neotropical migrant, and the results reinforced concerns that risks encountered during migration can contribute to species declines. Sillett and Holmes (2002) concluded that both habitat quality before migration as well as conditions during migration, including the number of communication towers encountered along the migratory route, affect mortality.

For short-lived species where a large proportion of individuals may only expect to have a single breeding season, spring mortality is biologically far more important and much less likely to be compensatory. Parulids can have annual mortality of 0.5-0.6 (Sillett and Holmes, 2002) and collectively have the second to shortest maximum lifespan ( 6 years maximum) of all passerine families (Wasser and Sherman, 2010). Although tower mortality is typically higher in the fall (both because of the presence of juvenile birds and the higher probability of weather patterns conducive to kills), it is estimated that $25 \%$ of mortality still occurs in the spring (Crawford and Engstrom, 2001). Whatever the split between spring and fall, a loss of $1-9 \%$ of the total population of a species each year to tower mortality may indeed influence population trajectories, especially for species already in decline (Robbins et al., 1989).

\subsection{Uncertainty}

Estimates of regional species profiles that were documented as part of long-term records from multiple sites are more reliable than those from shorter records encompassing fewer locations, but it is not possible to provide confidence estimates for our quantification of these estimates. Some regions have not reached asymptotes in species accumulation; the addition of new tower mortality locations and further data would result in spreading the calculated mortality for those regions across more species, potentially changing the apparent effect on those species identified here. It is for this reason that we have not reported the results for the shortgrass prairie regions, which had fewer than 1000 specimens available from towers (Table 1).

The accuracy of the total population estimates also influences the per species assessments. The method of calculating these estimates from breeding bird surveys (Rosenberg and Blancher, 2005) was well received, but has acknowledged limitations (Thogmartin et al., 2006). These population estimates have associated measures of accuracy and precision. For the 20 species ranked as highest annual percent mortality in our analysis, nearly all estimates of accuracy for landbirds are described as either "likely to be well within correct order of magnitude, often within $50 \%$ of true number" or "in correct order of magnitude" (Rich et al., 2004). Obviously, higher or lower estimates by an order of magnitude could increase or decrease the estimated population impact dramatically. For example, incorporating a 50\% range around the population 
Table 5

The ten species of birds killed most at communication towers in each region, as calculated by weighted averages of proportions killed at each location (see 2. Methods).

\begin{tabular}{|c|c|c|c|c|c|c|c|c|}
\hline Overall rank and species & $\begin{array}{l}\text { Prairie } \\
\text { Potholes, } \\
\text { Badlands and } \\
\text { Prairies }\end{array}$ & $\begin{array}{l}\text { Southeastern } \\
\text { Coastal Plain } \\
\text { and others }\end{array}$ & $\begin{array}{l}\text { Central } \\
\text { Hardwoods }\end{array}$ & $\begin{array}{l}\text { Eastern } \\
\text { Tallgrass } \\
\text { Prairie }\end{array}$ & $\begin{array}{l}\text { Prairie Hardwood } \\
\text { Transition, Boreal } \\
\text { Hardwood Transition }\end{array}$ & $\begin{array}{l}\text { Appalachian } \\
\text { Mountains, } \\
\text { Piedmont }\end{array}$ & $\begin{array}{l}\text { Peninsular } \\
\text { Florida }\end{array}$ & $\begin{array}{l}\text { New England/ } \\
\text { Mid-Atlantic } \\
\text { Coast and others }\end{array}$ \\
\hline 1 Red-eyed Vireo & 1 & 1 & 3 & 2 & 3 & 1 & & 4 \\
\hline 2 Ovenbird & 2 & 3 & 1 & 1 & 1 & 4 & 2 & 1 \\
\hline 3 Common Yellowthroat & 6 & 2 & 2 & 7 & & 6 & 1 & 5 \\
\hline 4 Tennessee Warbler & & & 4 & 4 & 5 & 5 & & \\
\hline 5 Swainson's Thrush & 7 & & 8 & 10 & 2 & 3 & & 7 \\
\hline 6 American Redstart & & 5 & & & 9 & 10 & 5 & 9 \\
\hline 7 Magnolia Warbler & & 6 & 5 & 6 & 7 & 7 & & 10 \\
\hline 8 Bay-breasted Warbler & & & 7 & 8 & 8 & 2 & & 6 \\
\hline 9 Black-and-white Warbler & & 8 & 10 & & 10 & & 6 & \\
\hline 10 Yellow-rumped Warbler & & 4 & & 5 & & & & \\
\hline 11 Gray Catbird & 8 & 9 & 6 & 9 & & 9 & & \\
\hline 12 Blackpoll Warbler & & & & & 4 & & 4 & 3 \\
\hline 13 Chestnut-sided Warbler & & 10 & 9 & & & & & 8 \\
\hline 14 Palm Warbler & & 7 & & & & & 8 & \\
\hline $\begin{array}{l}15 \text { Black-throated Blue } \\
\text { Warbler }\end{array}$ & & & & & & & 3 & \\
\hline 16 Nashville Warbler & & & & 3 & & & & \\
\hline 17 Ruby-crowned Kinglet & & & & & & & & 2 \\
\hline 18 Northern Waterthrush & & & & & & & 10 & \\
\hline 20 Northern Parula & & & & & & & 7 & \\
\hline 21 Gray-cheeked Thrush & & & & & 6 & & & \\
\hline 25 Wood Thrush & & & & & & 8 & & \\
\hline 33 Yellow Warbler & 3 & & & & & & & \\
\hline 39 Dark-eyed Junco & 5 & & & & & & & \\
\hline 40 Cape May Warbler & & & & & & & 9 & \\
\hline 42 Sora & 10 & & & & & & & \\
\hline 44 Lincoln's Sparrow & 9 & & & & & & & \\
\hline 55 American Tree Sparrow & 4 & & & & & & & \\
\hline
\end{tabular}

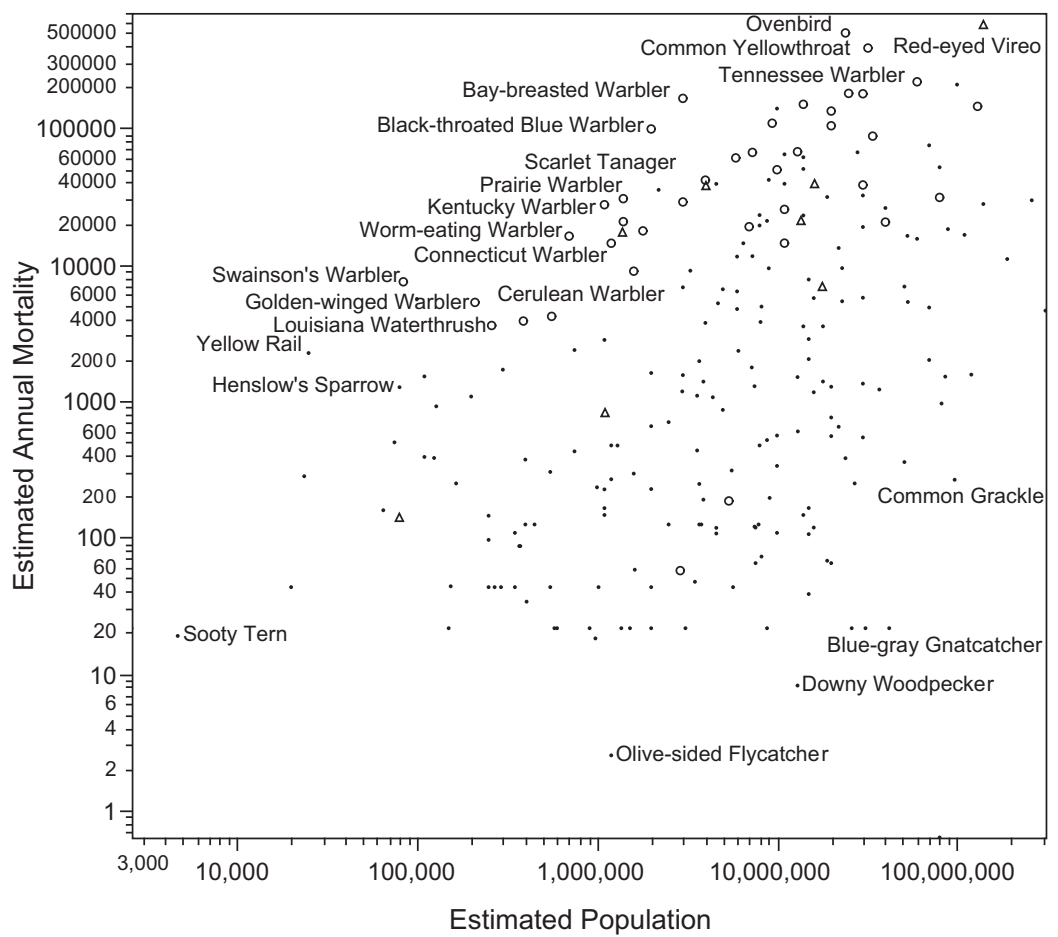

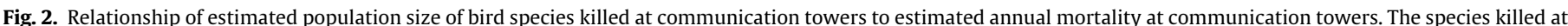

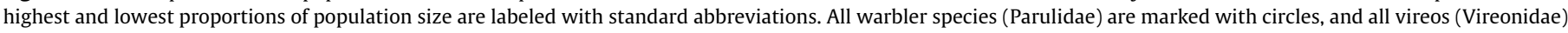
are marked with triangles.

estimate for Golden-winged Warbler (Vermivora chrysoptera) gives a range of annual mortality from $1.2 \%$ to $5.0 \%$ for our annual estimated mortality of $\sim 5300$ birds. Furthermore, the uncertainty of population estimates for species that are secretive, or whose ranges or habitats are not covered well by the Breeding Bird Survey, would likely be high. 
The results of the mortality assessment illustrate the potential complications of extrapolated species mortality from historical records. Yellow Rails (Coturnicops noveboracensis) winter along the Gulf Coast and breed in Canada (Bookhout, 1995). They have been recorded dead at towers across a large range and consequently are estimated to experience losses of $\sim 2200$ individuals per year. Towers almost certainly no longer kill as many Yellow Rails as they once did because of the dramatic decline of this species (Bookhout, 1995), although more recent mortality events do include 34 recorded in October 1986 (Ball et al., 1995) and 1 in Fall 2000 (Young and Robbins, 2001), both near Topeka, Kansas. We have assumed that the proportion of each species of bird killed has not changed, so estimates of mortality for some species that have declined dramatically may reflect historical rather than current patterns.

Additional uncertainty could arise from differential detectability of carcasses among species of different sizes (Smallwood, 2007). The effect of carcass size on overall mortality estimates is not likely to be substantial, however, because $97 \%$ of birds recovered at towers are small passerines (Table 2). We have not provided statistical estimates of uncertainty, but rather present the best possible estimates from the data currently available, with an explicit and transparent methodology that will allow improvement in these estimates as additional data are collected. It is, however, necessary to make such estimates because policies are currently being formulated to address incidental take from towers that could be informed by these efforts.

\subsection{Biological significance}

Advocates for the tower industry frequently compare avian mortality at towers to other sources of avian mortality and argue, implicitly or explicitly, that those sources that kill more total birds are more important by virtue of sheer numbers alone (e.g., Woodlot Alternatives, 2005). This approach is flawed for conservation assessments because it lumps all birds together without regard for their status as rare or common. Species are affected differentially and although total tower-related mortality is lower than some other sources of human-caused avian mortality, it can still be significant for individual species. This also applies to other sources of direct avian mortality, such as industrial-scale wind farms, where aggregate mortality numbers can appear to be low compared with other sources, but analysis for individual species can indicate significant impacts (Carrete et al., 2009).

An analysis of the biological significance of avian mortality at towers should consider other sources of human-caused mortality when those other sources are additive and can contribute to an assessment of cumulative impacts. For example, Klem (1990) estimated that glass windows kill on the order of 97.6 million to 976 million birds per year. Although no synthetic analyses of window collision mortality similar to this effort have been undertaken, Klem (1989) identified 20 avian species killed most frequently by windows from inquiries to 125 museum curators for information from their collections. Some of these species, such as Ovenbird (Seiurus aurocapilla), Swainson's Thrush (Catharus ustulatus), Common Yellowthroat (Geothlypis trichas), and Tennessee Warbler (Oreothlypis peregrina), are also killed in great numbers at towers. Although not comparable to our analysis, this approach helps to identify species for which cumulative impacts are likely to occur. For species at risk in such situations, addressing both tower and window mortality would be advisable and indeed the species killed in window strikes at tall buildings will be similar to those killed at communication towers. Although the 20 avian species killed most frequently at all windows reported by Klem (1989) do not contain any Birds of Conservation Concern, the 20 avian species killed most frequently at towers contain two such species (Bay-breasted Warbler [Setophaga castanea], and Blackpoll Warbler [Setophaga striata]) and 11 of 20 species killed in greatest proportion to their populations at towers have special conservation status.

The example of mortality at windows illustrates how mortality estimates from several human-caused sources can be used to weigh alternative policy options to protect migratory birds. First, per species estimates (or at least ranks) are needed. Then, for any particular species of concern, conservation action can be focused on a single source of mortality or address the cumulative effects of multiple sources. This decision cannot be made without some quantification of which bird species are killed by which causes or by integrating multiple sources of mortality into lifecycle models for individual species (Loss et al., 2012). For example, Gray Catbirds (Dumetella carolinensis) are among the birds killed most frequently at towers (Table 1) and are killed frequently by free-roaming cats (Balogh et al., 2011) and windows (Klem, 1989). Indeed, mortality from domestic cats alone is capable of reducing local catbird populations (Balogh et al., 2011). Cumulatively, these mortality sources may affect local and regional distribution and abundances even if no rangewide population-level effect is detected from any one source.

Finally, we have illustrated that it is feasible to develop per species estimates of avian mortality, even if the data are imperfect and assumptions are many. Notwithstanding these limitations, our method improves on current approaches to describing lethal effects of human activities on birds, where comparisons are made routinely of the number of "birds" killed with little consideration of which species are affected (e.g., Erickson et al., 2005; Gore, 2009). Such comparisons of undifferentiated totals of birds killed are insufficient to assess the biological significance of different mortality sources. We therefore encourage increased consideration and description of the species composition of avian casualties resulting from human actions and policies.

\section{Acknowledgments}

The authors acknowledge the outstanding contribution of Herbert L. Stoddard and Tall Timbers Research Station in executing the long-term study of avian mortality at the WCTV tower, for which we had access to the data. Environment Canada, American Bird Conservancy, and Defenders of Wildlife provided financial support for the early stages of this research. The authors thank Gerald Winegrad, Caroline Kennedy, Joelle Gehring, and Eugene A. Young for productive discussions about this research and access to unpublished reports.

\section{References}

Able, K.P., 1966. Television tower mortality near Louisville. Kentucky Warbler 42, 27-28.

Allen, G.T., Ramirez, P., 1990. A review of bird deaths on barbed-wire fences. Wilson Bull. 102, 553-558.

Alsop III, F.J., Wallace, G.O., 1969. Spring tower-kill in Knox County. Migrant 40, 5758.

Anonymous, 1961. Large bird kills at TV towers. Bluebird 28, 9.

Arnold, T.W., Zink, R.M., 2011. Collision mortality has no discernable effect on population trends of North American birds. PLoS ONE 6, e24708.

Avery, M., Clement, T., 1972. Bird mortality at four towers in eastern North Dakotafall 1972. Prairie Nat. 4, 87-95.

Avery, M., Springer, P.F., Cassel, J.F., 1976. The effects of a tall tower on nocturnal bird migration-a portable ceilometer study. Auk 93, 281-291.

Avery, M.L., Springer, P.F., Cassel, J.F., 1978. The composition and seasonal variation of bird losses at a tall tower in southeastern North Dakota. Am. Birds 32, 11141121.

Avery, M.L., Springer, P.F., Dailey, N.S., 1980. Avian Mortality at Man-made Structures: An Annotated Bibliography (revised). U.S. Fish and Wildlife Service, Biological Services, Program, FWS/OBS-80/54.

Baird, J., 1970. Mortality of fall migrants at the Boylston television tower in 1970. Chickadee 40, 17-21.

Baird, J., 1971. Mortality of birds at the Boylston television tower in September of 1971. Chickadee 41, 20-23. 
Ball, L.G., Zyskowski, K., Escalona-Segura, G., 1995. Recent bird mortality at a Topeka television tower. Kansas Ornith. Soc. Bull. 46, 33-36.

Balogh, A.L., Ryder, T.B., Marra, P.P., 2011. Population demography of Gray Catbirds in the suburban matrix: sources, sinks and domestic cats. J. Ornith. 152, 717726.

Barbour, R.W., 1961. An unusual bird mortality at Lexington. Kentucky Warbler 37, 55.

Barkley, R., Elk, C., Palmquist, J., 1977. Recent TV tower kills at Goodland. Kansas. Kansas Ornith. Soc. Bull. 28, 10-12.

Bierly, M.L., 1968. Television tower casualties at Birmingham in 1967. Alabama Birdlife 16, 34-35.

Bierly, M.L., 1969. 1968 Birmingham tower casualties. Alabama Birdlife 17, 46-49. Bierly, M.L., 1973. 1971 Fall television tower casualties in Nashville. Migrant 44, 56.

Bookhout, T.A., 1995. Yellow Rail (Cotunicops noveboracensis). In: Poole, A. (Ed.), The Birds of North America Online. Cornell Lab of Ornithology, Ithaca.

Boso, B., 1965. Bird casualties at a southeastern Kansas TV tower. Trans. Kans. Acad. Sci. 68, 131-136.

Brewer, R., Ellis, J.A., 1958. An analysis of migrating birds killed at a television tower in east-central Illinois, September 1955-May 1957. Auk 75, 400-414.

Brown, S., Hickey, C., Harrington, B., Gill, R. (Eds.), 2001. United States Shorebird Conservation Plan, Manomet Center for Conservation Sciences, second ed. Manomet, Massachusetts.

Caldwell, L.D., Cuthbert, N.L., 1963. Bird mortality at television towers near Cadillac, Michigan. Jack-Pine Warbler 41, 80-89.

Caldwell, L.D., Wallace, G.J., 1966. Collections of migrating birds at Michigan television towers. Jack-Pine Warbler 44, 117-123.

Carrete, M., Sánchez-Zapata, J.A., Benítez, J.R., Lobón, M., Donázar, J.A., 2009. Large scale risk-assessment of wind-farms on population viability of a globally endangered long-lived raptor. Biol. Conserv. 142, 2954-2961.

Carter III, J.H., Parnell, J.F., 1976. TV tower kills in eastern North Carolina. Chat 40, 19.

Carter III, J.H., Parnell, J.F., 1978. TV tower kills in eastern North Carolina: 1973 through 1977. Chat 42, 67-70.

Case, L.D., Cruickshank, H., Ellis, A.E., White, W.F., 1965. Weather causes heavy bird mortality. Florida Nat. 38, 29-30.

Cochran, W.W., Graber, R.R., 1958. Attraction of nocturnal migrants by lights on a television tower. Wilson Bull. 70, 378-380.

Crawford, R.L., 1976. Some old records of TV tower kills from southwest Georgia. Oriole 41, 45-51.

Crawford, R.L., Engstrom, R.T., 2001. Characteristics of avian mortality at a north Florida television tower: a 29-year study. J. Field Ornithol. 72, 380-388.

Dickerman, R.W., Winker, K., Gibson, D.D., 1998. Sooty Tern reaches the Aleutian Islands, Alaska. Western Birds 29, 122-123.

Drewitt, A.L., Langston, R.H.W., 2008. Collision effects of wind-power generators and other obstacles on birds. Ann. N.Y. Acad. Sci. 1134, 233-266.

Elder, W.H., Hansen, J., 1967. Bird mortality at KOMU-TV tower, Columbia, Missouri, fall 1965 and 1966. Bluebird 34, 3-7.

Ellis, C.D., 1997. Back to the tower: tower-killed birds at a Putnam County, West Virginia television transmission tower. Redstart 64, 111-113.

Erickson, W.P., Johnson, G.D., Young, Jr., D.P., 2005. A summary and comparison of bird mortality from anthropogenic causes with an emphasis on collisions. In: Ralph, C.J., Rich, T.D. (Eds.), Bird Conservation Implementation and Integration in the Americas: Proceedings of the Third International Partners in Flight Conference. USDA Forest Service Gen. Tech. Rep. PSW-GTR-191. Pacific Southwest Research Station, Forest Service, U.S. Department of Agriculture, Albany, California, pp. 1029-1042.

Feehan, J., 1963. Destruction of birdlife in Minnesota-September 1963. II. Birds killed at the Ostrander television tower. Flicker 35, 111-112.

Ganier, A.F., 1962. Bird casualties at a Nashville T-V tower. Migrant 33, 58-60.

Gauthreaux Jr., S.A., Belser, C.G., 2006. Effects of artificial night lighting on migrating birds. In: Rich, C., Longcore, T. (Eds.), Ecological Consequences of Artificial Night Lighting. Island Press, Washington, DC, pp. 67-93.

Gehring, J., Kerlinger, P., Manville II, A.M., 2009. Communication towers, lights, and birds: successful methods of reducing the frequency of avian collisions. Ecol. Appl. 19, 505-514.

George, W., 1963. Columbia tower fatalities. Bluebird 30, 5.

Ginter, D.L., Desmond, M.J., 2004. Avian mortality during fall 2001 migration at communication towers along the Rio Grande corridor in southern New Mexico. Southwest. Nat. 49, 414-417.

Goodpasture, K.A., 1974a. Fall 1972 television tower casualties in Nashville. Migrant $45,29-31$.

Goodpasture, K.A., 1974b. Fall 1973 television tower casualties in Nashville. Migrant 45, 57-59.

Goodpasture, K.A., 1975. Nashville television tower casualties, 1974. Migrant 46, 49-51.

Goodpasture, K.A., 1976. Nashville television tower casualties, 1975. Migrant 47, 810.

Goodpasture, K.A., 1984. Television tower casualties, Nashville, Tennessee 19761983. Migrant 55, 53-57.

Goodpasture, K.A., 1986. Nashville, Tennessee television tower casualties, 1984. Migrant 57, 70-72.

Goodpasture, K.A., 1987. 1985 Tower casualties at WSMV, Nashville, Tennessee. Migrant 58, 85-86.

Gore, A., 2009. Our choice: a plan to solve the climate crisis. Rodale Books, Emmaus, Pennsylvania.
Graber, R.R., 1968. Nocturnal migration in Illinois-different points of view. Wilson Bull. 80, 36-71.

Green, J.C., 1963. Destruction of birdlife in Minnesota-September 1963. III. Notes on kills at Duluth on September 18/19. Flicker 35, 112-113.

Gregory, H., 1975. Unusual fall tower kill. Bluebird 42, 9-10.

Herndon, L.R., 1973. Bird kill on Holston Mountain. Migrant 44, 1-4.

Herron, J., 1997. Television transmission tower kills in Lewis County, West Virginia. Redstart 64, 114-117.

Houston, C.S., Houston, M.I., 1975. The fall migration: northern Great Plains. Am. Birds 29, 74-76.

Hutto, R.L., 2000. On the importance of en route periods to the conservation of migratory landbirds. Stud. Avian Biol. 20, 109-114.

James, P., 1956. Destruction of warblers on Padre Island, Texas in May, 1951. Wilson Bull. 68, 224-227.

Janssen, R.B., 1963. Destruction of birdlife in Minnesota-September 1963. I. Birds killed at the Lewisville television tower. Flicker 35, 110-111.

Johnston, D.W., 1955. Mass bird mortality in Georgia, October, 1954. Oriole 20, 17 26.

Johnston, D.W., 1957. Bird mortality in Georgia, 1957. Oriole 22, 33-39.

Johnston, D.W., Haines, T.P., 1957. Analysis of mass bird mortality in October, 1954 Auk 74, 447-458.

Kale II, H.W., 1971. The spring migration: Florida region. Am. Birds 25, 723-735.

Kemper, C., 1996. A study of bird mortality at a west central Wisconsin TV tower from 1957-1995. Passenger Pigeon 58, 219-235.

Kemper, C.A., 1964. A tower for TV: 30,000 dead birds. Audubon Mag. 66, 86-90.

Kemper, C.A., Raveling, D.G., Warner, D.W., 1966. A comparison of the species composition of two TV tower killed samples from the same night of migration. Wilson Bull. 78, 26-30.

Kerlinger, P., 2000. Avian mortality at communication towers: a review of recent literature, research, and methodology. United States Fish and Wildlife Service, Office of Migratory Bird Management.

Kleen, V.M., Bush, L., 1973. The fall migration: middlewestern prairie region. Am. Birds 27, 66-70.

Klem Jr., D., 1989. Bird-window collisions. Wilson Bull. 101, 606-620.

Klem Jr., D., 1990. Collisions between birds and windows: mortality and prevention. J. Field Ornithol. 61, 120-128.

Klem Jr., D., De Groot, K.L., Krebs, E.A., Fort, K.T., Elbin, S.B., Prince, A., 2012. A second critique of 'Collision mortality has no discernable effect on population trends of North American Birds'. PLoS ONE 6, e24708 (comments).

Kushlan, J.A., Steinkamp, M.J., Parsons, K.C., Capp, J., Cruz, M.A., Coulter, M. Davidson, I., Dickson, L., Edelson, N., Elliot, R., Erwin, R.M., Hatch, S., Kress, S., Milko, R., Miller, S., Mills, K., Paul, R., Philips, R., Saliva, J.E., Sydeman, B., Trapp, J., Wheeler, J., Wohl, K., 2002. Waterbird conservation for the Americas: the North American waterbird conservation plan, version 1. Waterbird Conservation for the Americas, Washington, DC.

Lahrman, F.W., 1959. TV tower casualty list. Blue Jay 17, 142-143.

Lahrman, F.W., 1962. Fall migration TV tower kills, 1962. Blue Jay 20, 152.

Lahrman, F.W., 1965. Regina and Lumsden TV tower bird mortalities, 1964. Blue Jay 23, 18-19.

Laskey, A.R., 1962. Migration data from television tower casualties at Nashville. Migrant 33, 7-8.

Laskey, A.R., 1963. Mortality of night migrants at Nashville T V towers, 1963. Migrant 34, 65-66.

Laskey, A.R., 1964. Data from the Nashville T.V. tower casualties autumn 1964. Migrant 35, 95-96.

Laskey, A.R., 1967. Spring mortality of Black-poll Warblers at a Nashville T.V. tower Migrant 38, 43.

Laskey, A.R., 1968. Television tower casualties at Nashville, autumn 1967. Migrant 39, 25-26.

Laskey, A.R., 1969a. Autumn 1969 T.V. tower casualties at Nashville. Migrant 40 79-80.

Laskey, A.R., 1969b. T.V. tower casualties at Nashville in autumn 1968. Migrant 40 25-27.

Laskey, A.R., 1971. T.V. tower casualties at Nashville: spring and autumn, 1970. Migrant 42, 15-16.

Longcore, T., Rich, C., Gauthreaux, S.A., Jr., 2005. Scientific basis to establish policy regulating communications towers to protect migratory birds: response to Avatar Environmental, LLC., report regarding migratory bird collisions with communications towers, WT Docket No. 03-187. Federal Communications Commission Notice of Inquiry. Land Protection Partners, Los Angeles, California pp. 1-33.

Longcore, T., Rich, C., Gauthreaux Jr., S.A., 2008. Height, guy wires, and steadyburning lights increase hazard of communication towers to nocturnal migrants: a review and meta-analysis. Auk 125, 485-492.

Longcore, T., Rich, C., Mineau, P., MacDonald, B., Bert, D.G., Sullivan, L.M., Mutrie, E. Gauthreaux Jr., S.A., Avery, M.L., Crawford, R.L., Manville II, A.M., Travis, E.R., Drake, D., 2012. An estimate of avian mortality at communication towers in the United States and Canada. PLoS ONE 7, e34025.

Loss, S.R., Will, T., Marra, P.P., 2012. Direct human-caused mortality of birds: improving quantification of magnitude and assessment of population impact. Front. Ecol. Environ. 10, 357-364.

Manuwal, D.D., 1963. TV transmitter kills in South Bend, Indiana, fall 1962. Indiana Audubon Quart. 41, 49-53.

Manville, A.M., II, 2005. Bird strikes and electrocutions at power lines, communication towers, and wind turbines: state of the art and state of the science - next steps toward mitigation. In: Ralph, C.J., Rich, T.D. (Eds.), Bird 
Conservation Implementation and Integration in the Americas: Proceedings of the Third International Partners in Flight Conference. USDA Forest Service Gen. Tech. Rep. PSW-GTR-191. Pacific Southwest Research Station, Forest Service, U.S. Department of Agriculture, Albany, California, pp. 1051-1064.

Manville, A.M., II, 2007. Comments of the U.S. Fish and Wildlife Service submitted electronically to the FCC on 47 CFR Parts 1 and 17, WT Docket No. 03-187, FCC 06-164, Notice of Proposed Rulemaking, Effects of Communication Towers on Migratory Birds. U.S. Fish and Wildlife Service, Washington, DC, pp. 1-32.

Manville, A.M., II, 2009. Towers, turbines, power lines, and buildings - steps being taken by the U.S. Fish and Wildlife Service to avoid or minimize take of migratory birds at these structures. In: Rich, T.D., Arizmendi, C., Demarest, D.W., Thompson, C. (Eds.), Tundra to Tropics: Connecting Birds, Habitats and People; Proceedings of the Fourth International Partners in Flight Conference, 13-16 February, 2008. Partners in Flight, McAllen, Texas, pp. 262-272.

Mayfield, H., 1967. Shed few tears. Audubon Mag. 69, 61-65.

Morris, S.R., Clark, A.R., Bhatti, L.H., Glasgow, J.L., 2003. Television tower mortality of migrant birds in western New York and Youngstown. Ohio. Northeast. Nat. 10, 67-76.

Mosman, D. 1975. Bird casualties at Alleman, Ia. TV tower. Iowa Bird Life 45, 88-90.

Nehring, J., Bivens, S., 1999. A study of bird mortality at Nashville's WSMV television tower. Migrant 70, 1-8.

Nero, R.W., 1961. Regina TV tower bird mortalities-1961. Blue Jay 19, 160-164.

Nero, R.W., 1962. Regina TV tower mortality: May 11-12, 1962. Blue Jay 20, 151152.

Nicholson, C.P., 1984. September 1984 tower kill in Knox County, Tennessee. Migrant 55, 86

Nielsen, L.A., Wilson, K.R., 2006. Clear Channel of northern Colorado Slab Canyon KQLF-FM broadcasting tower avian monitoring project 2002-2004. EDM International, Inc. and Colorado State University, Fort Collins, Colorado, pp. 1-38.

Norman, J.L., 1987. Synopsis of birds killed at the Coweta, Oklahoma, TV tower 1974-1984. Bull. Oklahoma Ornith. Soc. 20, 17-22.

North American Waterfowl Management Plan Committee, 2004. North American Waterfowl management plan 2004. Strengthening the biological foundation: strategic guidance. Environment Canada, Canadian Wildlife Service, U.S Department of Interior, Fish and Wildlife Service; Secretaría de Medio Ambiente y Recursos Naturales.

Norwood, J.R., 1960. TV tower casualties at a Charlotte station. Chat 24, 103-104.

Palmer-Ball Jr., B., Rauth, L., 1990. Tower mortality in Henderson County. Kentucky Warbler 66, 97-98.

Parmalee, P.W., Parmalee, B.G., 1959. Mortality of birds at a television tower in central Illinois. Audubon Bull. [Illinois Audubon Society] 111, 1-4.

Parmalee, P.W., Thompson, M.D., 1963. A second kill of birds at a television tower in central Illinois. Audubon Bull. [Illinois Audubon Society] 128, 13-15.

Petersen Jr., P.C., 1959. TV tower mortality in western Illinois. Audubon Bull. [Illinois Audubon Society] 112, 14-15.

Pierce, M.E., 1969. Tall television tower and bird migration. South Dakota Bird Notes $21,4-5$.

Reed, J.M., Blaustein, A.R., 1997. Biologically significant population declines and statistical power. Conserv. Biol. 11, 281-282.

Remy Jr., R.J., 1974. Birmingham tower casualties: fall, 1974. Alabama Birdlife 22, 910.

Remy Jr., R.J., 1975. Birmingham television tower casualties, 1975. Alabama Birdlife $23,18-19$.

Rich, T.D., Beardmore, C.J., Berlanga, H., Blancher, P.J., Bradstreet, M.S.W., Butcher, G.S., Demarest, D.W., Dunn, E.H., Hunter, W.C., Iñigo-Elias, E.E., Kennedy, J.A., Martell, A.M., Panjabi, A.O., Pashley, D.N., Rosenberg, K.V., Rustay, C.M., Wendt, J.S., Will, T.C., 2004. Partners in Flight North American landbird conservation plan. Cornell Lab of Ornithology, Ithaca, New York.

Robbins, C.S., Sauer, J.R., Greenberg, R.S., Droege, S., 1989. Population declines in North American birds that migrate to the neotropics. Proc. Natl. Acad. Sci. USA $86,7658-7662$

Robbins, M.B., Barber, B.R., Young, E.A., 2000. Major bird mortality at a Topeka television tower. Kansas Ornith. Soc. Bull. 51, 29-30.

Rosche, R.C., 1971. The fall migration: western New York and northwestern Pennsylvania. Am. Birds 25, 54-57.

Rosenberg, K.V., Blancher, P.J., 2005. Setting numerical population objectives for priority landbird species. In: Ralph, C.J., Rich, T.D. (Eds.), Bird Conservation Implementation and Integration in the Americas: Proceedings of the Third International Partners in Flight Conference. USDA Forest Service Gen. Tech. Rep.
PSW-GTR-191. Pacific Southwest Research Station, Forest Service, U.S. Department of Agriculture, Albany, California, pp. 57-67.

Sawyer, P.J., 1961. Bird mortality at the WENH-TV tower in Deefield, New Hampshire. New Hampshire Audubon Quarterly 14, 46-49.

Schaub, M., Kéry, M., Korner, P., Kornder Nievergelt, F., 2011. A critique of Collison mortality has no discernable effect on population trends of North American Birds. PLoS ONE 6, e24708 (comments).

Seets, J.W., Bohlen, H.D., 1977. Comparative mortality of birds at television towers in central Illinois. Wilson Bull. 89, 422-433.

Sharp, B., 1971. Heavy mortality of migrating birds at Madison's TV towers. Passenger Pigeon 33, 203-204.

Shire, G.G., Brown, K., Winegrad, G., 2000. Communication towers: a deadly hazard to birds. American Bird Conservancy, Washington, DC, pp. 1-23.

Sillett, T.S., Holmes, R.T., 2002. Variation in survivorship of a migratory songbird throughout its annual cycle. J. Anim. Ecol. 71, 296-308.

Smallwood, K.S., 2007. Estimating wind turbine-caused bird mortality. J. Wildl. Manage. 71, 2781-2791

Strnad, F., 1962. Birds killed at the KROC-TV tower, Ostrander, Minnesota. Flicker 34, 7-9.

Strnad, F.V., 1975. More bird kills at KROC-TV tower, Ostrander, Minnesota. Loon 47, 16-21.

Taylor, W.K., Anderson, B.H., 1973. Nocturnal migrants killed at a central Florida TV tower; autumns 1969-1971. Wilson Bull. 85, 42-51.

Taylor, W.K., Anderson, B.H., 1974. Nocturnal migrants killed at a central Florida TV tower, autumn 1972. Florida Field Natur. 2, 40-43.

Teulings, R.P., 1972. The fall migration: southern Atlantic coast region. Am. Birds 26, $45-50$

Thogmartin, W.E., Howe, F.P., James, F.C., Johnson, D.H., Reed, E.T., Sauer, J.R., Thompson III, F.R., 2006. A review of the population estimation approach of the North American Landbird Conservation Plan. Auk 123, 892-904.

Trail, P.W., 2006. Avian mortality at oil pits in the United States: a review of the problem and efforts for its solution. Environ. Manage. 38, 532-544.

Trapp, J.L., 1998. Bird kills at towers and other human-made structures: an annotated partial bibliography (1960-1998). U.S. Fish and Wildlife Service, Office of Migratory Bird Management, Arlington, Virginia.

Travis, E., 2009. Impacts of Communication Towers on Avian Migrants, pp. 1-94. MS Thesis, Department of Forest and Wildlife Ecology, University of WisconsinMadison.

Trott, J., 1957. TV tower fatalities at Chapel Hill. Chat 21, 28.

Turner, L., Davis, M., 1980. Birds killed at television towers in Knox County. Migrant 51, 27-29.

U.S. Fish and Wildlife Service, 2000. Service Guidance on The Siting, Construction, Operation and Decommissioning of Communications Towers. U.S. Fish and Wildlife Service, Washington, DC.

U.S. Fish and Wildlife Service, 2008. Birds of Conservation Concern 2008. Division of Migratory Bird Management, Arlington, Virginia, pp. 1-85.

Wasser, D.E., Sherman, P.W., 2010. Avian longevities and their interpretation under evolutionary theories of senescence. J. Zool. 280, 103-155.

Weir, R.D., 1976. Annotated bibliography of bird kills at man-made obstacles: a review of the state of the art and solutions. Department of Fisheries and the Environment, Environmental Management Service, Canadian Wildlife Service, Ontario Region, Ottawa.

Welles, M., 1978. TV tower kill at Elmira. Kingbird 28, 159-161.

Westman, F. 1967. Casualties at station CKVR-TV, Barrie, in O.E. Devitt (Ed.). The birds of Simcoe County, Ontario. Brereton Field Naturalists' Club, Barrie, Ontario, vol. 180 , pp. $18-19$.

Woodlot Alternatives, 2005. Technical comment on Notice of Inquiry Comment Review, Avian/Communication Tower Collisions, Final (Avatar et al. 2004) Report prepared for CTIA - The Wireless Association, The National Association of Broadcasters, and PCIA - The Wireless Infrastructure Association. Woodot Alternatives, Inc., Topsham, Maine, pp. 1-7.

Young, E.A., 1993. Bird mortality at the Boise City Loran-C tower, Cimarron County, Oklahoma, fall 1992. Report to U.S. Fish and Wildlife Service, Ecological Services, Tulsa, Oklahoma, pp. 1-51, Arkansas City, Kansas.

Young, E.A., Robbins, M.B., 2001. Bird mortality at the KTKA-TV tower, near Topeka, Kansas, 1998-2000 (Grant \# 60181-8-P269). Report to the U.S. Fish and Wildlife Service, Region 6 Nongame Migratory Bird Program. Cowley County Community College and Museum of Natural History, The University of Kansas, Arkansas City, Kansas and Lawrence, Kansas, pp. 1-10. 